\title{
Design, synthesis and biological potential of heterocyclic benzoxazole scaffolds as promising antimicrobial and anticancer agents
}

\author{
Saloni Kakkar', Sanjiv Kumar', Balasubramanian Narasimhan ${ }^{1 *} \mathbb{D}$, Siong Meng Lim²,3, Kalavathy Ramasamy ${ }^{2,3}$,
} Vasudevan Mani ${ }^{4}$ and Syed Adnan Ali Shah ${ }^{2,5}$

\begin{abstract}
Background: Benzoxazole is the most important class of heterocyclic compound in medicinal chemistry. It has been incorporated in many medicinal compounds making it a versatile heterocyclic compound that possess a wide spectrum of biological activities.

Results: The molecular structures of synthesized benzoxazole derivatives were confirmed by physicochemical and spectral means. The synthesized compounds were further evaluated for their in vitro biological potentials i.e. antimicrobial activity against selected microbial species using tube dilution method and antiproliferative activity against human colorectal carcinoma (HCT 116) cancer cell line by Sulforhodamine B assay.

Conclusion: In vitro antimicrobial results demonstrated that compounds 4, 5, $\mathbf{7}$ and $\mathbf{1 6}$ showed promising antimicrobial potential. The in vitro anticancer activity indicated that compounds $\mathbf{4}$ and $\mathbf{1 6}$ showed promising anticancer activity against human colorectal cancer cell line (HCT 116) when compared to standard drug and these compounds may serve as lead compound for further development of novel antimicrobial and anticancer agents.
\end{abstract}

Keywords: Benzoxazole molecules, Synthesis, Antimicrobial activity, Anticancer activity

\section{Background}

Colorectal cancer is one of the most dangerous forms of cancer, causing the deaths of many patients every year [1]. As such, a significant progress is being made continuously towards developing novel chemotherapeutic agents $[2,3]$. One of the standard drugs for treatment of colorectal cancer is 5-fluorouracil (5-FU). However it is associated with a lot of side effects as it not only affects the cancer cells but also the normal cells [3-7]. In order to overcome the undesirable side effects of available anticancer agents there is a need to develop novel

\footnotetext{
*Correspondence: naru2000us@yahoo.com

1 Faculty of Pharmaceutical Sciences, Maharshi Dayanand University, Rohtak 124001, India

Full list of author information is available at the end of the article
}

chemotherapeutic agents for more effective cancer treatment [2].

The number of cases of multidrug resistant bacterial infections is increasing at an alarming rate and clinicians have become reliant on vancomycin as the antibiotic for serious infections resistant to traditional agents which indicated that there is a need for the development of new classes of antimicrobial agents [8]. Hence there is a need to develop those agents whose chemical characteristics clearly differ from those existing agents and can overcome the problem of resistance [9].

Benzoxazole belongs to one of the most important class of heterocyclic compounds which are very significant for medicinal field. It has been incorporated in many medicinal compounds that made it versatile heterocyclic compound possessing wide spectrum of biological activities viz: antimicrobial [10, 11], analgesic/anti-inflammatory 
[12], antitumor [13], antidiabetic activity [14] etc. Keeping in view of the pharmacological importance of benzoxazole derivatives, the present study had synthesize some new benzoxazole derivatives and evaluate their antimicrobial and antiproliferative activities. The design of benzoxazole molecules with antimicrobial and anticancer potential was based on literature as shown in Fig. 1.

\section{Results and discussion}

\section{Chemistry}

A series of benzoxazole derivatives (1-20) was synthesized using synthetic procedures as outlined in Scheme 1. Initially, 2-chloro- $N$-(substituted phenyl)acetamide (I) was prepared by reacting substituted aniline with chloroacetyl chloride in the presence of acetone and powdered potassium carbonate. To prepare 2-azido- $N$-(substituted phenyl)acetamide (II) reaction was carried out between I in dry DMF and sodium azide at room temperature. Benzo $[d]$ oxazole-2-thiol (III) was prepared from 2-aminophenol in methanol, potassium hydroxide followed by the addition of carbon-di-sulphide. Further, to a solution of III in acetone was added anhydrous potassium carbonate powder followed by slow addition of 3-bromoprop-1-yne at $0{ }^{\circ} \mathrm{C}$ and the obtain 2-(prop-2-yn-1-ylthio) benzo $[d]$ oxazole (IV). Finally, II and IV were dissolved in a mixture of $\mathrm{t}-\mathrm{BuOH}: \mathrm{H}_{2} \mathrm{O}$ :DMF followed by the addition of sodium ascorbate and copper (II) sulfate so as to obtain target benzoxazole derivatives $(\mathbf{1 - 2 0})$. The synthesized compounds were confirmed by physicochemical properties (Table 1) i.e. melting point, molecular formula, $R_{f}$ value, \% yield and spectral interpretation details (Table 2 ) i.e. FT-IR, NMR and Mass, which are in agreement with

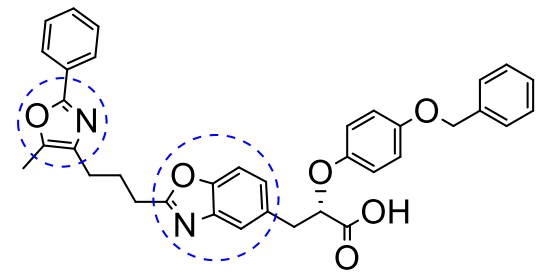

Antimicrobial agent (Zhang et al., 2011)

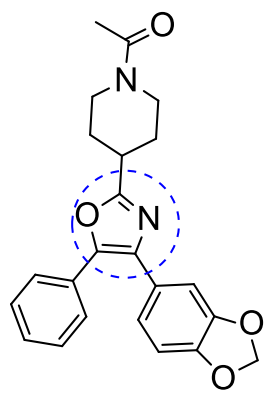

Antimicrobial agent (Reddy et al., 2013

[20]

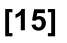

[15]

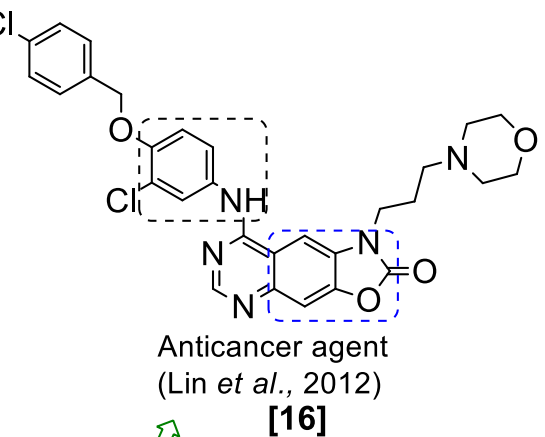

[16]

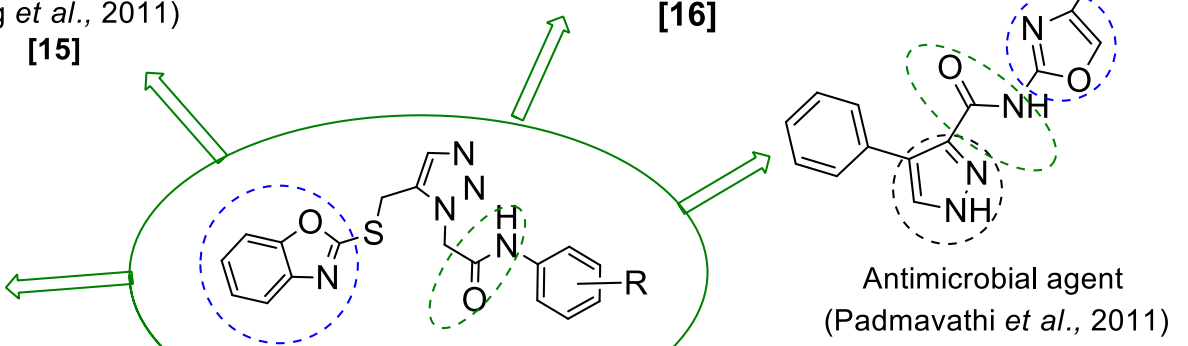

(Padmavathi et al., 2011)

[17]

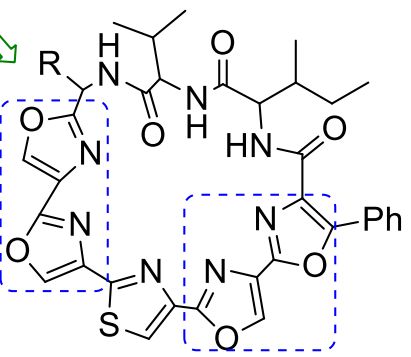

Anticancer agent

(Hernández et al., 2008)

[18] 


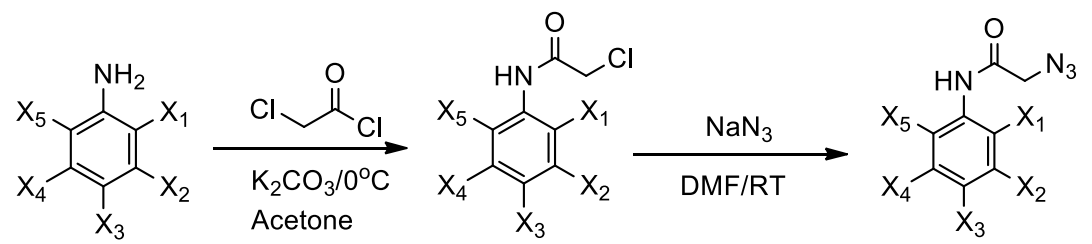

Substituted anilines

2-Chloro- $N$-(substituted phenyl)acetamide

2-Azido- $N$-(substituted phenyl)acetamide

(I)

(II)

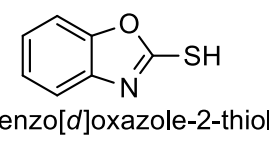

(III)

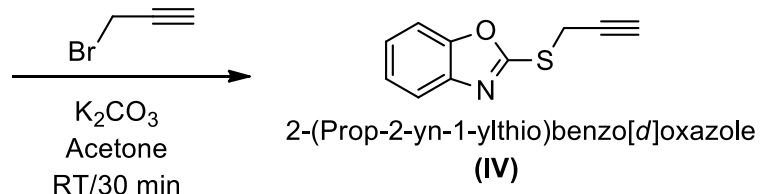<smiles>[Y4]c1c([Y4])c([Y4])c(NC(=O)CN)c([Y4])c1[Y]</smiles>

2-Azido- $N$-(substituted phenyl)acetamide

(II)<smiles>C#CCSc1nc2ccccc2o1</smiles>

2-(Prop-2-ynylthio) benzo[d]oxazole

(IV)<smiles>[Y4]c1c([Y4])c([Y4])c(NC(=O)Cn2nncc2CSc2nc3ccccc3o2)c([Y4])c1[Y4]</smiles>

Benzoxazole derivatives

(1-20)
1. $\mathrm{X}_{1}=\mathrm{X}_{3}=\mathrm{X}_{4}=\mathrm{X}_{5}=\mathrm{H} ; \mathrm{X}_{2}=\mathrm{NO}_{2}$

2. $\mathrm{X}_{1}=\mathrm{X}_{2}=\mathrm{X}_{4}=\mathrm{X}_{5}=\mathrm{H} ; \mathrm{X}_{3}=\mathrm{NO}_{2}$

3. $\mathrm{X}_{1}=\mathrm{X}_{2}=\mathrm{X}_{4}=\mathrm{X}_{5}=\mathrm{H} ; \mathrm{X}_{3}=\mathrm{OCH}_{3}$

4. $\mathrm{X}_{2}=\mathrm{X}_{4}=\mathrm{X}_{5}=\mathrm{H} ; \mathrm{X}_{1}=\mathrm{Cl} ; \mathrm{X}_{3}=\mathrm{NO}_{2}$

$5 \mathrm{X}_{1}=\mathrm{X}_{3}=\mathrm{X}_{4}=\mathrm{Cl} ; \mathrm{X}_{2}=\mathrm{X}_{5}=\mathrm{H}$

6. $\mathrm{X}_{3}=\mathrm{X}_{4}=\mathrm{X}_{5}=\mathrm{H} ; \mathrm{X}_{1}=\mathrm{CH}_{3} ; \mathrm{X}_{2}=\mathrm{Cl}$

7. $\mathrm{X}_{2}=\mathrm{X}_{4}=\mathrm{X}_{5}=\mathrm{H} ; \mathrm{X}_{1}=\mathrm{CH}_{3} ; \mathrm{X}_{3}=\mathrm{Br}$

8. $\mathrm{X}_{1}=\mathrm{X}_{2}=\mathrm{X}_{4}=\mathrm{X}_{5}=\mathrm{H} ; \mathrm{X}_{3}=\mathrm{CH}_{2}-\mathrm{CH}_{3}$

9. $\mathrm{X}_{2}=\mathrm{X}_{4}=\mathrm{X}_{5}=\mathrm{H} ; \mathrm{X}_{1}=\mathrm{CH}_{3} ; \mathrm{X}_{3}=\mathrm{CH}_{3}$

10. $\mathrm{X}_{2}=\mathrm{X}_{3}=\mathrm{X}_{4}=\mathrm{X}_{5}=\mathrm{H} ; \mathrm{X}_{1}=\mathrm{Cl}$
11. $\mathrm{X}_{1}=\mathrm{X}_{2}=\mathrm{X}_{4}=\mathrm{X}_{5}=\mathrm{H} ; \mathrm{X}_{3}=\mathrm{F}$

12. $\mathrm{X}_{1}=\mathrm{X}_{2}=\mathrm{X}_{4}=\mathrm{X}_{5}=\mathrm{H} ; \mathrm{X}_{3}=\mathrm{Br}$

13. $\mathrm{X}_{1}=\mathrm{X}_{4}=\mathrm{X}_{5}=\mathrm{H} ; \mathrm{X}_{2}=\mathrm{X}_{3}=\mathrm{Cl}$

14. $\mathrm{X}_{2}=\mathrm{X}_{3}=\mathrm{X}_{4}=\mathrm{X}_{5}=\mathrm{H} ; \mathrm{X}_{1}=\mathrm{Br}$

15. $\mathrm{X}_{1}=\mathrm{X}_{3}=\mathrm{X}_{5}=\mathrm{H} ; \mathrm{X}_{2}=\mathrm{CH}_{3} ; \mathrm{X}_{4}=\mathrm{CH}_{3}$

16. $\mathrm{X}_{1}=\mathrm{X}_{3}=\mathrm{X}_{4}=\mathrm{X}_{5}=\mathrm{H} ; \mathrm{X}_{2}=\mathrm{Br}$

17. $\mathrm{X}_{3}=\mathrm{X}_{4}=\mathrm{X}_{5}=\mathrm{H} ; \mathrm{X}_{1}=\mathrm{X}_{2}=\mathrm{CH}_{3}$

18. $\mathrm{X}_{2}=\mathrm{X}_{3}=\mathrm{X}_{4}=\mathrm{X}_{5}=\mathrm{H} ; \mathrm{X}_{1}=\mathrm{F}$

19. $\mathrm{X}_{1}=\mathrm{X}_{3}=\mathrm{X}_{4}=\mathrm{X}_{5}=\mathrm{H} ; \mathrm{X}_{2}=\mathrm{Cl}$

20. $\mathrm{X}_{1}=\mathrm{X}_{2}=\mathrm{X}_{4}=\mathrm{X}_{5}=\mathrm{H} ; \mathrm{X}_{3}=\mathrm{Cl}$

Scheme 1 Synthesis of benzoxazole derivatives (1-20)

the proposed molecular structures. The three obvious peaks in the IR spectra of the title compounds at 1689$1662 \mathrm{~cm}^{-1}, 3315-2986 \mathrm{~cm}^{-1}$ and $1499-1408 \mathrm{~cm}^{-1}$ are attributed to $\mathrm{C}=\mathrm{N}$ group of oxazole ring, $\mathrm{C}-\mathrm{H}$ and $\mathrm{C}=\mathrm{C}$ groups of aromatic ring, respectively. The absorption peak of C-F group in aromatic fluoro compounds (11 and 18) appeared at $1235-1207 \mathrm{~cm}^{-1}$ whereas bands at $738-622 \mathrm{~cm}^{-1}$ correspond to $\mathrm{C}-\mathrm{Br}$ stretching of aromatic bromo derivatives $(7,12,14$ and 16). The presence of aryl alkyl ether group $\left(\mathrm{C}-\mathrm{O}-\mathrm{C}, \mathrm{Ar}-\mathrm{OCH}_{3}\right)$ in compound 3 showed a band at $1194 \mathrm{~cm}^{-1}$. Further the presence of chloro group $(\mathrm{Ar}-\mathrm{Cl})$ in compounds $5,6,10,13,19$ and 20 showed IR stretches at $744-739 \mathrm{~cm}^{-1}$. The IR band at $1653-1578 \mathrm{~cm}^{-1}$ indicated the presence of CONH group of synthesized compounds. The compounds 1,2 and 4 displayed IR stretching around $1394-1341 \mathrm{~cm}^{-1}$ that 
Table 1 Physicochemical properties of synthesized benzoxazole derivatives

\begin{tabular}{|c|c|c|c|c|c|}
\hline Comp. & Molecular mass & M. formula & m.p. ${ }^{\circ} \mathrm{C}$ & $\mathrm{R}_{f}$ value & $\%$ yield \\
\hline $\begin{array}{l}\text { 1: 2-(5-((Benzo[d]oxazol-2-ylthio)methyl)-1H-1,2,3-triazol-1-yl)-N-(3-nitrophenyl) } \\
\text { acetamide }\end{array}$ & 410.41 & $\mathrm{C}_{18} \mathrm{H}_{14} \mathrm{~N}_{6} \mathrm{O}_{4} \mathrm{~S}$ & $152-154$ & 0.17 & 76 \\
\hline $\begin{array}{l}\text { 2: 2-(5-((Benzo[d]oxazol-2-ylthio)methyl)-1H-1,2,3-triazol-1-yl)-N-(4-nitrophenyl) } \\
\text { acetamide }\end{array}$ & 410.41 & $\mathrm{C}_{18} \mathrm{H}_{14} \mathrm{~N}_{6} \mathrm{O}_{4} \mathrm{~S}$ & $165-167$ & 0.18 & 81 \\
\hline $\begin{array}{l}\text { 3: 2-(5-((Benzo[d]oxazol-2-ylthio)methyl)-1H-1,2,3-triazol-1-yl)-N-(4-methoxyphenyl) } \\
\text { acetamide }\end{array}$ & 395.43 & $\mathrm{C}_{19} \mathrm{H}_{17} \mathrm{~N}_{5} \mathrm{O}_{3} \mathrm{~S}$ & $102-104$ & 0.23 & 75 \\
\hline $\begin{array}{l}\text { 4: 2-(5-((Benzo[d]oxazol-2-ylthio)methyl)-1H-1,2,3-triazol-1-yl)-N-(2-chloro-4-nitro- } \\
\text { phenyl) acetamide }\end{array}$ & 444.85 & $\mathrm{C}_{18} \mathrm{H}_{13} \mathrm{CIN}_{6} \mathrm{O}_{4} \mathrm{~S}$ & $144-146$ & 0.20 & 86 \\
\hline $\begin{array}{l}\text { 5: 2-(5-((Benzo[d]oxazol-2-ylthio)methyl)-1H-1,2,3-triazol-1-yl)-N-(2,4,5-trichlorophe- } \\
\text { nyl) acetamide }\end{array}$ & 468.74 & $\mathrm{C}_{18} \mathrm{H}_{12} \mathrm{Cl}_{3} \mathrm{~N}_{5} \mathrm{O}_{2} \mathrm{~S}$ & 189-191 & 0.21 & 79 \\
\hline $\begin{array}{l}\text { 6: 2-(5-((Benzo[d]oxazol-2-ylthio)methyl)-1H-1,2,3-triazol-1-yl)-N-(3-chloro-2-meth- } \\
\text { ylphenyl) acetamide }\end{array}$ & 413.88 & $\mathrm{C}_{19} \mathrm{H}_{16} \mathrm{ClN}_{5} \mathrm{O}_{2} \mathrm{~S}$ & $138-140$ & 0.22 & 82 \\
\hline $\begin{array}{l}\text { 7: 2-(5-((Benzo[d]oxazol-2-ylthio)methyl)-1H-1,2,3-triazol-1-yl)-N-(4-bromo-2- } \\
\text { methyl-phenyl) acetamide }\end{array}$ & 458.33 & $\mathrm{C}_{19} \mathrm{H}_{16} \mathrm{BrN}_{5} \mathrm{O}_{2} \mathrm{~S}$ & $127-129$ & 0.22 & 85 \\
\hline $\begin{array}{l}\text { 8: 2-(5-((Benzo[d]oxazol-2-ylthio)methyl)-1H-1,2,3-triazol-1-yl)-N-(4-ethylphenyl) } \\
\text { acetamide }\end{array}$ & 393.46 & $\mathrm{C}_{20} \mathrm{H}_{19} \mathrm{~N}_{5} \mathrm{O}_{2} \mathrm{~S}$ & $118-120$ & 0.23 & 85 \\
\hline $\begin{array}{l}\text { 9: 2-(5-((Benzo[d]oxazol-2-ylthio)methyl)-1H-1,2,3-triazol-1-yl)-N-(2,4-dimethylphe- } \\
\text { nyl) acetamide }\end{array}$ & 393.49 & $\mathrm{C}_{20} \mathrm{H}_{19} \mathrm{~N}_{5} \mathrm{O}_{2} \mathrm{~S}$ & $108-110$ & 0.23 & 81 \\
\hline $\begin{array}{l}\text { 10: 2-(5-((Benzo[d]oxazol-2-ylthio)methyl)-1H-1,2,3-triazol-1-yl)-N-(2-chlorophenyl) } \\
\text { acetamide }\end{array}$ & 399.85 & $\mathrm{C}_{18} \mathrm{H}_{14} \mathrm{ClN}_{5} \mathrm{O}_{2} \mathrm{~S}$ & $144-146$ & 0.19 & 86 \\
\hline $\begin{array}{l}\text { 11: 2-(5-((Benzo[d]oxazol-2-ylthio)methyl)-1H-1,2,3-triazol-1-yl)-N-(4-fluorophenyl) } \\
\text { acetamide }\end{array}$ & 383.40 & $\mathrm{C}_{18} \mathrm{H}_{14} \mathrm{FN}_{5} \mathrm{O}_{2} \mathrm{~S}$ & $119-121$ & 0.19 & 90 \\
\hline $\begin{array}{l}\text { 12: 2-(5-((Benzo[d]oxazol-2-ylthio)methyl)-1H-1,2,3-triazol-1-yl)-N-(4-bromophenyl) } \\
\text { acetamide }\end{array}$ & 444.31 & $\mathrm{C}_{18} \mathrm{H}_{14} \mathrm{BrN}_{5} \mathrm{O}_{2} \mathrm{~S}$ & $172-174$ & 0.20 & 77 \\
\hline $\begin{array}{l}\text { 13: 2-(5-((Benzo[d]oxazol-2-ylthio)methyl)-1H-1,2,3-triazol-1-yl)-N-(3,4-dichlorophe- } \\
\text { nyl) acetamide }\end{array}$ & 434.30 & $\mathrm{C}_{18} \mathrm{H}_{13} \mathrm{Cl}_{2} \mathrm{~N}_{5} \mathrm{O}_{2} \mathrm{~S}$ & 169-171 & 0.19 & 80 \\
\hline $\begin{array}{l}\text { 14: 2-(5-((Benzo[d]oxazol-2-ylthio)methyl)-1H-1,2,3-triazol-1-yl)-N-(2-bromophenyl) } \\
\text { acetamide }\end{array}$ & 444.31 & $\mathrm{C}_{18} \mathrm{H}_{14} \mathrm{BrN}_{5} \mathrm{O}_{2} \mathrm{~S}$ & $131-133$ & 0.19 & 81 \\
\hline $\begin{array}{l}\text { 15: 2-(5-((Benzo[d]oxazol-2-ylthio)methyl)-1H-1,2,3-triazol-1-yl)-N-(3,5-dimethyl- } \\
\text { phenyl) acetamide }\end{array}$ & 393.46 & $\mathrm{C}_{20} \mathrm{H}_{19} \mathrm{~N}_{5} \mathrm{O}_{2} \mathrm{~S}$ & $125-127$ & 0.23 & 79 \\
\hline $\begin{array}{l}\text { 16: 2-(5-((Benzo[d]oxazol-2-ylthio)methyl)-1H-1,2,3-triazol-1-yl)-N-(3-bromophenyl) } \\
\text { acetamide }\end{array}$ & 444.31 & $\mathrm{C}_{18} \mathrm{H}_{14} \mathrm{BrN}_{5} \mathrm{O}_{2} \mathrm{~S}$ & $151-153$ & 0.18 & 78 \\
\hline $\begin{array}{l}\text { 17: 2-(5-((Benzo[d]oxazol-2-ylthio)methyl)-1H-1,2,3-triazol-1-yl)-N-(2,3-dimethyl- } \\
\text { phenyl) acetamide }\end{array}$ & 393.46 & $\mathrm{C}_{20} \mathrm{H}_{19} \mathrm{~N}_{5} \mathrm{O}_{2} \mathrm{~S}$ & 133-135 & 0.24 & 82 \\
\hline $\begin{array}{l}\text { 18: 2-(5-((Benzo[d]oxazol-2-ylthio)methyl)-1H-1,2,3-triazol-1-yl)-N-(2-fluorophenyl) } \\
\text { acetamide }\end{array}$ & 383.40 & $\mathrm{C}_{18} \mathrm{H}_{14} \mathrm{FN}_{5} \mathrm{O}_{2} \mathrm{~S}$ & $119-120$ & 0.20 & 89 \\
\hline $\begin{array}{l}\text { 19: 2-(5-((Benzo[d]oxazol-2-ylthio)methyl)-1H-1,2,3-triazol-1-yl)-N-(3-chlorophenyl) } \\
\text { acetamide }\end{array}$ & 399.85 & $\mathrm{C}_{18} \mathrm{H}_{14} \mathrm{ClN}_{5} \mathrm{O}_{2} \mathrm{~S}$ & $161-163$ & 0.19 & 86 \\
\hline $\begin{array}{l}\text { 20: 2-(5-((Benzo[d]oxazol-2-ylthio)methyl)-1H-1,2,3-triazol-1-yl)-N-(4-chlorophenyl) } \\
\text { acetamide }\end{array}$ & 399.85 & $\mathrm{C}_{18} \mathrm{H}_{14} \mathrm{CIN}_{5} \mathrm{O}_{2} \mathrm{~S}$ & $166-168$ & 0.19 & 82 \\
\hline
\end{tabular}

corresponds to $\mathrm{C}-\mathrm{N}$ symmetric stretching of aromatic $\mathrm{NO}_{2}$ group.

In ${ }^{1} \mathrm{H}-\mathrm{NMR}$ spectra the multiplet signals between 6.70 and $8.57 \mathrm{ppm}$ are assigned to the presence of aromatic protons of synthesized compounds (1-20). The compound 3 showed a singlet at $3.71 \mathrm{ppm}$ due to the existence of $-\mathrm{OCH}_{3}$ of $\mathrm{Ar}-\mathrm{OCH}_{3}$ in its structure. All the synthesized compounds showed a singlet at 7.34$7.14 \mathrm{ppm}$ which corresponds to the presence of $\mathrm{N}-\mathrm{CH}$ of triazole. Compounds, 6, 7, 9, 15 and 17 showed singlet around $2.50 \mathrm{ppm}$ due to the existence of $-\mathrm{CH}_{3}$ group at ortho and para position. The appearance of singlet at $4.72-4.77 \mathrm{ppm}$ and $8.27-7.82 \mathrm{ppm}$ are due to $-\mathrm{CH}_{2}$ and $-\mathrm{NH}$ group, respectively. ${ }^{13} \mathrm{C}-\mathrm{NMR}$ spectral data showed the confirmation of carbon atom in the assigned molecular structures of the synthesized compounds. The mass spectra of title compounds shows consistency between $[\mathrm{M}]^{+}$ion absorption signal and the calculated molecular weight. The synthesized benzoxazole derivatives (1-20) were screened for their pharmacological activity i.e. antimicrobial and antiproliferative activities against selected microbial (bacterial and fungal) organisms and cancer cell line (HCT 116), respectively (using standard protocol shown in experimental section). The 
Kakkar et al. Chemistry Central Journal (2018) 12:96

Page 5 of 11

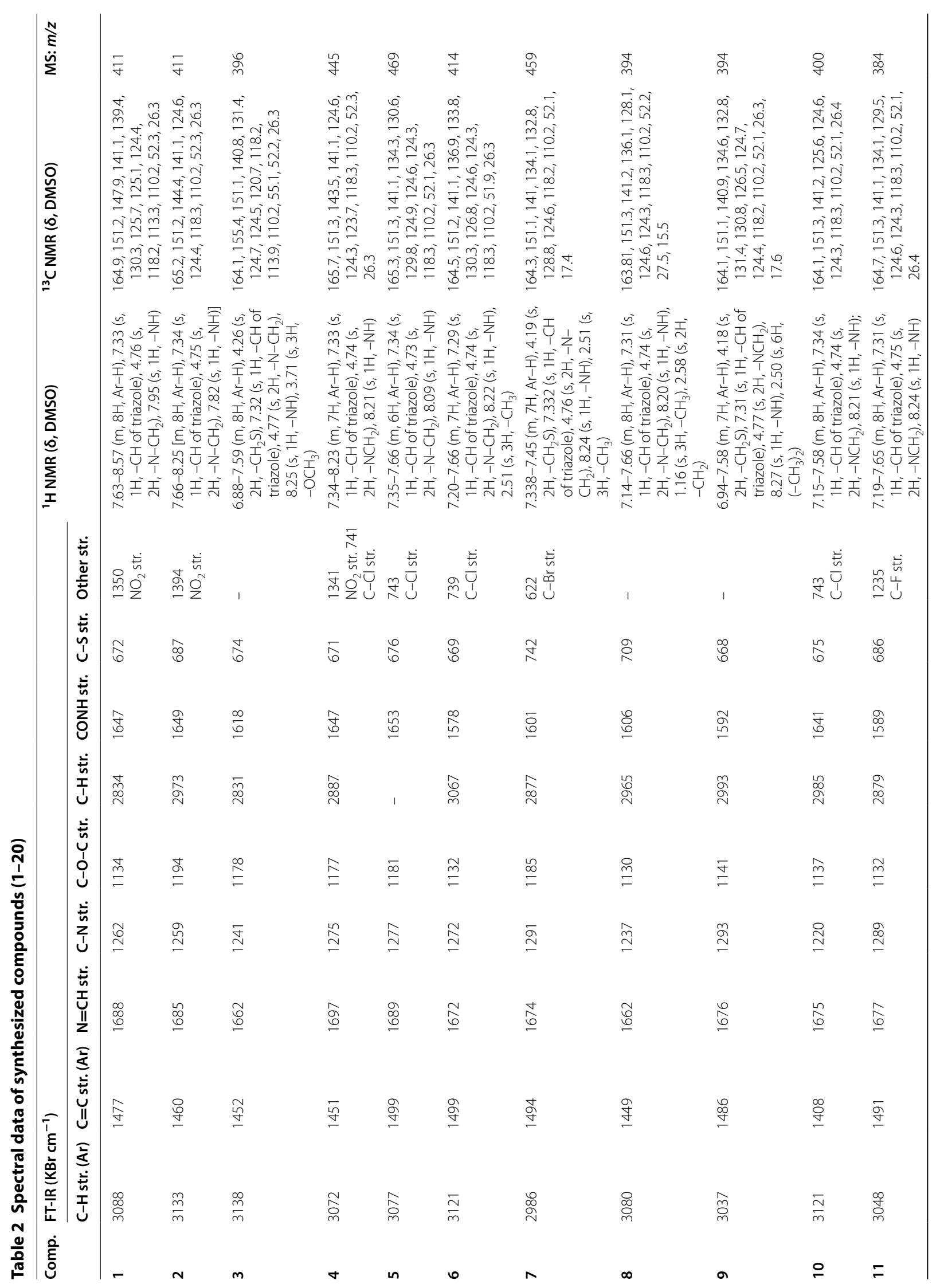







structure-activity relationship study of the synthesized compounds indicated that the compounds bearing electron withdrawing group at different position of the substituted portion showed the promising antimicrobial and anticancer potentials.

\section{In vitro antimicrobial activity}

The synthesized benzoxazole compounds (1-20) were investigated for their antimicrobial potential against selected Gram-positive (S. aureus, B. subtilis), Gramnegative (E. coli, K. pneumoniae, S. typhi) bacterial and fungal ( $C$. albicans, A. niger) organisms by tube dilution method (Table 3, Figs. 2 and 3). In case of Grampositive bacteria, compound $5\left(\mathrm{MIC}_{b s}=13.3 \mu \mathrm{M}\right.$ and $\mathrm{MIC}_{s t}=26.7 \mu \mathrm{M}$ ) showed the significant activity against B. Subtilis and S. typhi, respectively. Other side, compound $4\left(\mathrm{MIC}_{s a, a n}=28.1 \mu \mathrm{M}\right.$ and $\left.\mathrm{MIC}_{e c}=14 \mu \mathrm{M}\right)$ showed promising activity against $S$. aureus, $A$. niger and E. coli, respectively. Compound $7\left(\mathrm{MIC}_{k p}\right.$, $\left.{ }_{\mathrm{ca}}=27.3 \mu \mathrm{M}\right)$ exhibited good activity against $K$. pneumoniae and C. albicans. Whereas, compound $\mathbf{1 6}$ was found to be most active one against $A$. niger with MIC value of $28.1 \mu \mathrm{M}$. In this series compound 4 having high antimicrobial potential among the synthesized compounds may be taken as lead compound for the development of novel antimicrobial agent.

\section{In vitro anticancer activity}

The antiproliferative activity of the benzoxazole derivatives was assessed against the human colorectal cancer cell line (HCT 116 (ATCC CCL-247). Antiproliferative screening results (Table 4) revealed that compounds $4\left(\mathrm{IC}_{50}=22.5 \mu \mathrm{M}\right)$ and $16\left(\mathrm{IC}_{50}=38.3 \mu \mathrm{M}\right)$ displayed most promising antiproliferative activity in reference to the standard drug 5 -fluorouracil $\left(\mathrm{IC}_{50}=12.2 \mu \mathrm{M}\right)$.

\section{Structure activity relationship (SAR)}

The structure activity relationship for antimicrobial and anticancer activities of synthesized benzoxazole derivatives (SAR, Fig. 4) can be deduced as follows:

- Presence of two heterocyclic moieties i.e. benzoxazole and triazole in the synthesized compounds, showed the promising in vitro antimicrobial and anticancer activities against the selected microbial organisms and cancer cell line, respectively.

- Presence of electron withdrawing groups $\left(\mathrm{Cl}\right.$ and $\left.\mathrm{NO}_{2}\right)$ at ortho and para-positions, respectively of the substituted portion (Compound 4), enhanced the antimicrobial activity against $S$. aureus, E. coli, A. niger and antiproliferative activity against HCT 116 cancer cell line.
- Presence of electron releasing group $\left(\mathrm{CH}_{3}\right)$ at ortho and electron withdrawing group $(\mathrm{Br})$ at para-position of the substituted portion (Compound 7) enhanced the antimicrobial activity against $K$. pneumoniae and $C$. albicans.

- Electron withdrawing group $(\mathrm{Br})$ at meta-position of the substituted portion (Compound 16), enhanced the antifungal and antiproliferative activities against $A$. niger and HCT 116 cancer cell line, respectively, as well as compound $\mathbf{5}$ have electron withdrawing group $(\mathrm{Cl})$ at ortho and para-position of the substituted portion played an effective role in improving the antibacterial activity against B. subtilis and S. typhi.

The structure-activity relationship of the synthesized benzoxazole derivatives indicated that the compounds bearing electron withdrawing and electron releasing groups at different position of the substituted portion plays an excellent role in improving the antimicrobial and antiproliferative activities. The aforementioned facts are supported by the earlier research findings [21-23].

\section{Experimental section}

Material and reagents

The materials required to carry out this research work were obtained from commercial sources and were used with no further purification. Reaction monitoring was carried by thin-layer chromatography using $0.25 \mathrm{~mm}$ silica gel plates, using chloroform and methanol (9:1) as mobile phase and iodine vapours helped in observing the spots which were visualized in UV light. Melting point of compounds was determined by open capillary tube technique. An infrared spectrum was recorded (ATR, $\mathrm{cm}^{-1}$ ) in Bruker 12060280, software: OPUS 7.2.139.1294 spectrometer. ${ }^{1} \mathrm{H}-\mathrm{NMR}$ and ${ }^{13} \mathrm{C}-\mathrm{NMR}$ were recorded at 600 and $150 \mathrm{MHz}$, respectively on Bruker Avance III 600 NMR spectrometer by appropriate deuterated solvents. The results are conveyed in parts per million $(\delta, \mathrm{ppm})$ downfield from tetramethylsilane (internal standard). ${ }^{1} \mathrm{H}-\mathrm{NMR}$ spectral details of the synthesized derivatives are represented with multiplicity like singlet (s); doublet $(\mathrm{d})$; triplet $(\mathrm{t})$; multiplet $(\mathrm{m})$ and the number hydrogen ion. Waters Micromass Q-ToF Micro instrument was utilized for obtaining the Mass spectra.

General procedure for synthesis of benzoxazole derivatives (1-20)

Step A: Synthesis of 2-chloro- $N$-(substituted phenyl) acetamide derivatives (I)

To a stirred solution of substituted aniline $(10 \mathrm{mmol})$ in acetone $(35 \mathrm{ml})$ at $0{ }^{\circ} \mathrm{C}$ was added powdered potassium carbonate $(50 \mathrm{mmol})$. After stirring the mixture for $30 \mathrm{~min}$ at $0{ }^{\circ} \mathrm{C}$, chloroacetyl chloride $(20 \mathrm{mmol})$ was added dropwise with vigorous stirring. The mixture was 
Table 3 In vitro antimicrobial activity of the synthesized compounds

\begin{tabular}{|c|c|c|c|c|c|c|c|}
\hline \multirow[t]{3}{*}{ Compound no. } & \multicolumn{7}{|c|}{ Antimicrobial results $(\mathrm{MIC}=\mu \mathrm{M})$} \\
\hline & \multicolumn{5}{|c|}{ Bacterial species } & \multicolumn{2}{|c|}{ Fungal species } \\
\hline & $B S$ & $S A$ & $E C$ & $S T$ & $K P$ & $A N$ & $C A$ \\
\hline 1 & 60.9 & 60.9 & 121.8 & 60.9 & 60.9 & 60.9 & 30.5 \\
\hline 2 & 30.5 & 60.9 & 60.9 & 30.5 & 60.9 & 60.9 & 60.9 \\
\hline 3 & 31.6 & 63.2 & 63.2 & 31.6 & 63.2 & 63.2 & 31.6 \\
\hline 4 & 28.1 & 28.1 & 14.0 & 28.1 & 56.2 & 28.1 & 28.1 \\
\hline 5 & 13.3 & 53.3 & 106.7 & 26.7 & 53.3 & 53.3 & 53.3 \\
\hline 6 & 30.2 & 30.2 & 30.2 & 60.4 & 30.2 & 30.2 & 30.2 \\
\hline 7 & 27.3 & 54.5 & 54.5 & 54.5 & 27.3 & 54.5 & 27.3 \\
\hline 8 & 15.9 & 63.5 & 63.5 & 63.5 & 63.5 & 31.8 & 63.5 \\
\hline 9 & 15.9 & 63.5 & 15.9 & 63.5 & 31.8 & 31.8 & 31.8 \\
\hline 10 & 31.3 & 31.3 & 31.3 & 31.3 & 31.3 & 31.3 & 31.3 \\
\hline 11 & 16.3 & 65.2 & 16.3 & 32.6 & 32.6 & 32.6 & 65.2 \\
\hline 12 & 56.3 & 56.3 & 56.3 & 56.3 & 56.3 & 112.5 & 56.3 \\
\hline 13 & 57.6 & 57.6 & 57.6 & 57.6 & 57.6 & 115.1 & 57.6 \\
\hline 14 & 28.1 & 56.3 & 14.1 & 28.1 & 56.3 & 56.3 & 28.1 \\
\hline 15 & 15.9 & 63.5 & 15.9 & 31.8 & 63.5 & 31.8 & 31.8 \\
\hline 16 & 14.1 & 56.3 & 56.3 & 56.3 & 56.3 & 28.1 & 56.3 \\
\hline 17 & 31.8 & 63.5 & 15.9 & 31.8 & 63.5 & 31.8 & 63.5 \\
\hline 18 & 16.3 & 65.2 & 32.6 & 32.6 & 32.6 & 32.6 & 32.6 \\
\hline 19 & 15.6 & 62.5 & 62.5 & 62.5 & 62.5 & 31.3 & 31.3 \\
\hline 20 & 31.3 & 62.5 & 62.5 & 62.5 & 62.5 & 125.0 & 125.0 \\
\hline Ofloxacin & 17.3 & 34.6 & 34.6 & 34.6 & 34.6 & - & - \\
\hline Fluconazole & - & - & - & - & - & 40.8 & 40.8 \\
\hline
\end{tabular}

BS: Bacillus subtilis; SA: Staphylococcus aureus; EC: Escherichia coli; ST: Salmonella typhi; KP: Klebsiella pneumoniae; AN: Aspergillus niger; CA: Candida albicans

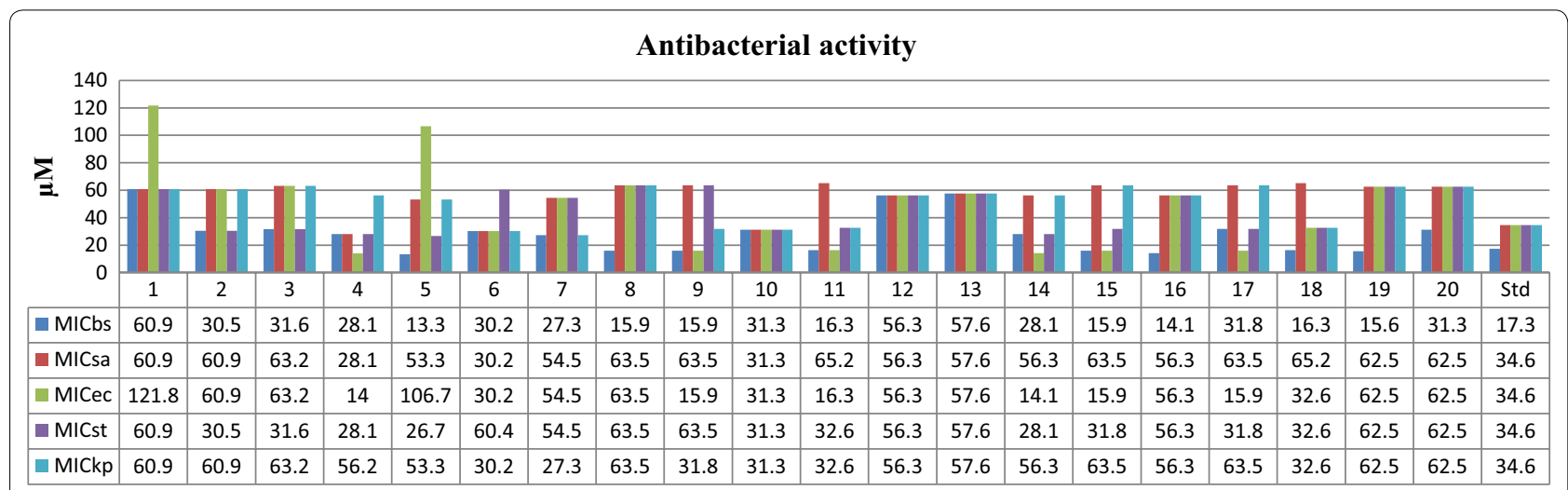

Fig. 2 Antibacterial screening results of the synthesized benzoxazole derivatives

then continuously stirred at room temperature for $3 \mathrm{~h}$. The mixture was then poured into water $(400 \mathrm{ml})$ with stirring. The separated solid was filtered and washed with hexane $(50 \mathrm{ml})$ to give the desired intermediate $\mathbf{I}$ in good yield.
Step B: Synthesis of 2-azido- $N$-(substituted phenyl)acetamide derivatives (II)

To a stirred solution of $\mathbf{I}(3.0 \mathrm{mmol})$ in dry DMF (15 ml) was slowly added sodium azide $(6.0 \mathrm{mmol})$. The resulting reaction mixture was then stirred for $12 \mathrm{~h}$ at room 


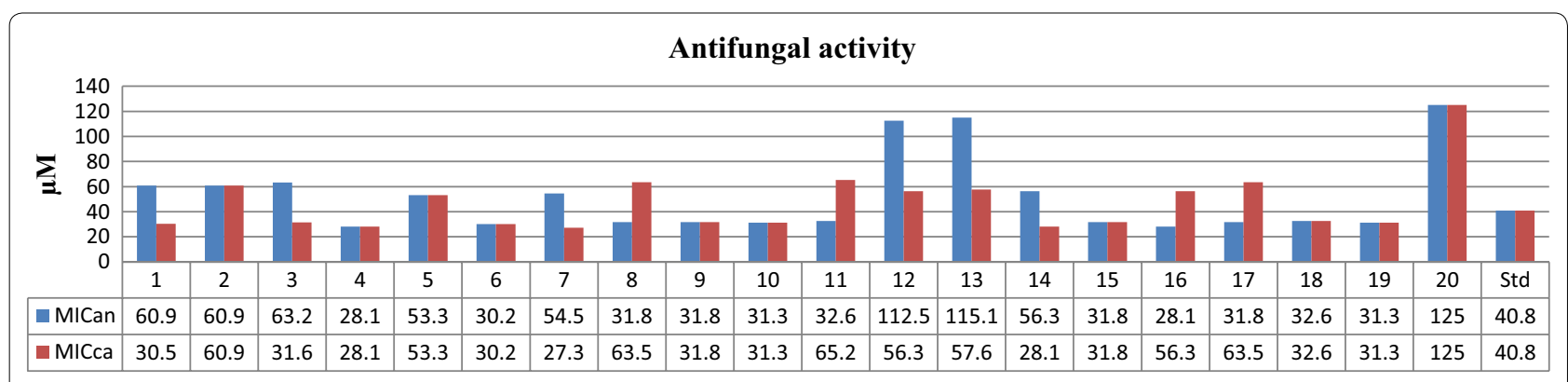

Fig. 3 Antifungal screening results of the synthesized benzoxazole derivatives

\section{Table 4 Anticancer activity results of synthesized compounds}

\begin{tabular}{lccc}
\hline \multicolumn{4}{l}{ Anticancer screening results $\left(\mathrm{IC}_{\mathbf{5 0}}=\boldsymbol{\mu M}\right)$} \\
\hline Compound no. & $\begin{array}{l}\text { Cancer cell } \\
\text { line (HCT 116) }\end{array}$ & Compound no. & $\begin{array}{l}\text { Cancer cell } \\
\text { line (HCT } \\
\mathbf{1 1 6})\end{array}$ \\
\hline $\mathbf{1}$ & 97.5 & $\mathbf{1 1}$ & 130.4 \\
$\mathbf{2}$ & 73.1 & $\mathbf{1 2}$ & $>225.1$ \\
$\mathbf{3}$ & 108.7 & $\mathbf{1 3}$ & $>230.3$ \\
$\mathbf{4}$ & 22.5 & $\mathbf{1 4}$ & 90.0 \\
$\mathbf{5}$ & 85.3 & $\mathbf{1 5}$ & 40.7 \\
$\mathbf{6}$ & 84.6 & $\mathbf{1 6}$ & 38.3 \\
$\mathbf{7}$ & 72.0 & $\mathbf{1 7}$ & 177.9 \\
$\mathbf{8}$ & 254.2 & $\mathbf{1 8}$ & 148.7 \\
$\mathbf{9}$ & 66.1 & $\mathbf{1 9}$ & 50.0 \\
$\mathbf{1 0}$ & 175.1 & $\mathbf{2 0}$ & 200.1 \\
$\mathbf{5 - F l u o r o u r a c i l}$ & 12.2 & $\mathbf{5 - F l u o r o u r a c i l}$ & 12.2 \\
\hline
\end{tabular}

temperature. The mixture was then poured into ice cold water $(100 \mathrm{ml})$ with stirring. The separated solid was filtered and washed with water $(50 \mathrm{ml})$ to give the desired compound II in good yield.

\section{Step C: Synthesis of benzo[d]oxazole-2-thiol (III)}

To a solution of 2-aminophenol $(100 \mathrm{mmol})$ in methanol $(150 \mathrm{ml})$ was added aqueous potassium hydroxide $(130 \mathrm{mmol})$ in water $(30 \mathrm{ml})$, followed by addition of carbon-di-sulfide $(150 \mathrm{mmol})$. Resulting mixture was refluxed at $65{ }^{\circ} \mathrm{C}$ for $5 \mathrm{~h}$. After the completion of reaction, reaction mixture was poured in water $(500 \mathrm{ml})$, which was neutralized with conc. hydrochloric acid and the solid separated was filtered and washed with hexane to afford the pure compound III (Yield: 90\%). MP: $168-170{ }^{\circ} \mathrm{C}$.

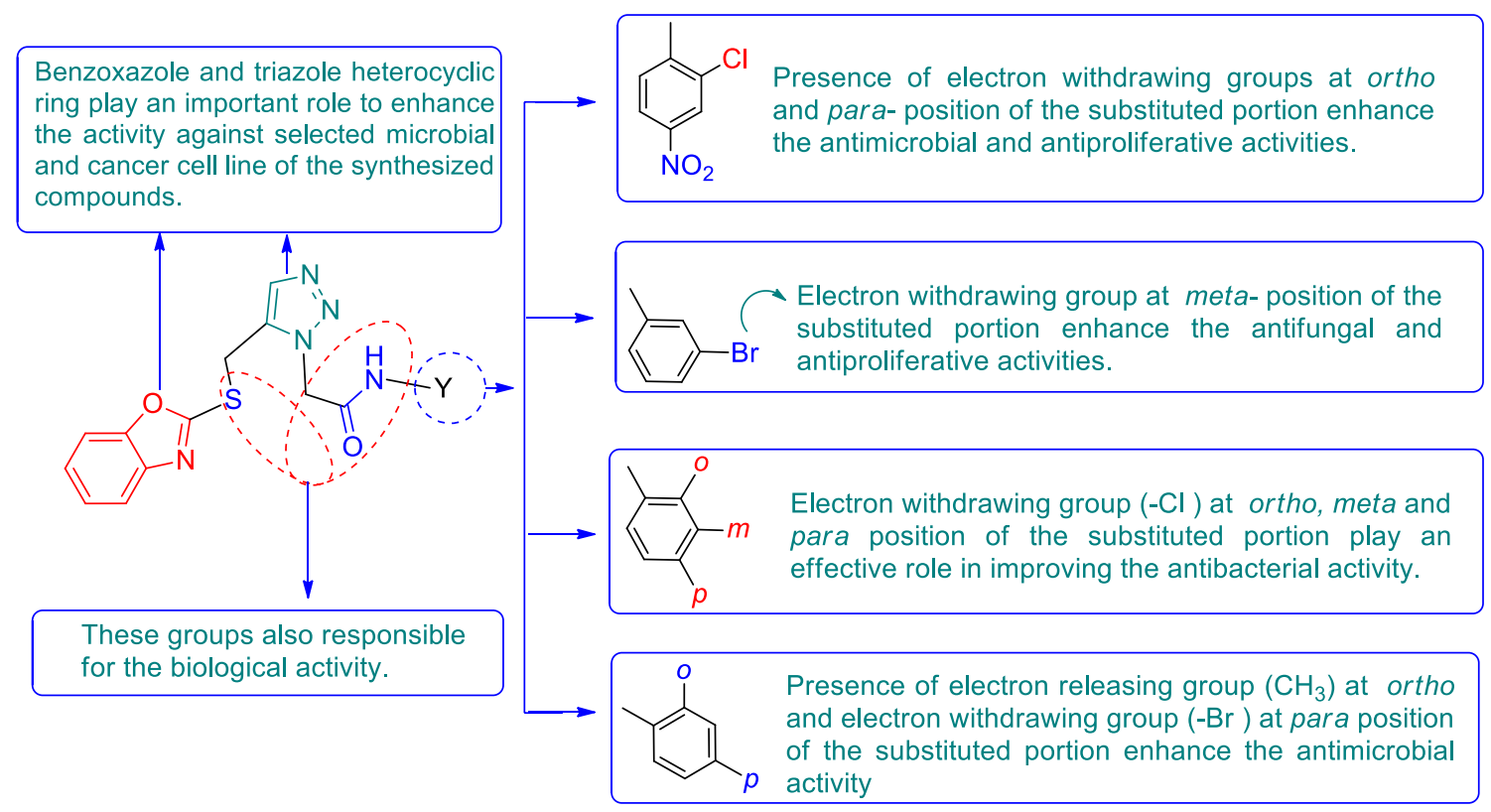

Fig. 4 Structure activity relationship of benzoxazole derivatives 
Step D: Synthesis of 2-(prop-2-ynylthio)benzo[d]oxazole (IV) To a solution of III $(50 \mathrm{mmol})$ in acetone $(150 \mathrm{ml})$ was added anhydrous potassium carbonate powder $(100 \mathrm{mmol})$ with stirring. After $5 \mathrm{~min}$, propargyl bromide (55 mmol) was added slowly at $0{ }^{\circ} \mathrm{C}$ and allowed to stir for $30 \mathrm{~min}$ at room temperature. After completion of the reaction, followed by TLC, the mixture was quenched with ice cold water $(500 \mathrm{ml})$ with vigorous stirring. The solid product separated was filtered followed by washing with water $(50 \mathrm{ml})$ which afforded the desired intermediate IV (Yield: $8.7 \mathrm{~g}, 92 \%)$. MP: $188-190^{\circ} \mathrm{C}$.

\section{Step E: Synthesis of target compounds (1-20)}

The intermediates IV $(1.5 \mathrm{mmol})$ and $\mathbf{I I}(1.5 \mathrm{mmol})$ were dissolved in a mixture of $\mathrm{t}-\mathrm{BuOH}: \mathrm{H}_{2} \mathrm{O}: \mathrm{DMF}$ mixture $(6 \mathrm{ml}, 1: 1: 1)$. Sodium ascorbate $(0.75 \mathrm{mmol})$ was added, followed by copper (II) sulfate $(0.3 \mathrm{mmol})$. The mixture was stirred vigorously at room temperature until TLC indicated the disappearance of the starting materials (30 min). After completion of the reaction as monitored by TLC $\left(\mathrm{CHCl}_{3}: \mathrm{MeOH} / 9: 1\right.$, Rf: 0.17$)$, solid separated in the reaction mass was then filtered and washed with water $(10 \mathrm{ml})$ followed by methanol $(10 \mathrm{ml})$ to give pure benzoxazole derivatives.

\section{In vitro antimicrobial assay}

The antimicrobial testing of the benzoxazole derivatives (1-20) was done by tube dilution method [24] against ofloxacin (antibacterial) and fluconazole (antifungal) as standard drugs using Gram-positive (B. Subtilis MTCC441; S. aureus, MTCC-3160) and Gram-negative bacteria (E. coli, MTCC-443; S. typhi, MTCC-98; K. pneumoniae, MTCC-530). The antifungal activity was assayed against (C. albicans, MTCC-227) and mould (A. niger, MTCC281). Serial dilutions of the test compounds and reference drugs were prepared in double strength nutrient broth I.P. (bacteria) or sabouraud dextrose broth I.P. (fungi) [25]. The stock solution of the test and reference compounds was prepared in dimethyl sulfoxide. The samples were incubated at $37 \pm 1{ }^{\circ} \mathrm{C}$ for $24 \mathrm{~h}$ (bacteria), at $25 \pm 1{ }^{\circ} \mathrm{C}$ for 7 days $\left(\right.$ A. niger) and at $37 \pm 1{ }^{\circ} \mathrm{C}$ for $48 \mathrm{~h}$ (C. albicans), respectively and the results were recorded in terms of MIC. The MIC was the lowest concentration of the tested compound that yields no visible growth of microorganisms in the test tube.

\section{In vitro anticancer assay}

The antiproliferative effect of benzoxazole derivatives was determined against the human colorectal carcinoma [HCT 116] cancer cell line using the Sulforhodamine-B (SRB) assay. HCT 116 was seeded at 2500 cells/ well (96 well plate). The cells were allowed to attach overnight before being exposed to the respective compounds $(0.001-100 \mu \mathrm{g} / \mathrm{mL})$ for $72 \mathrm{~h}$. The highest concentration of each compound tested $(100 \mu \mathrm{g} / \mathrm{ml})$ contained only $0.1 \%$ DMSO (non-cytotoxic). SRB assay [26] was then performed. Trichloroacetic acid was used to fix the cell. Staining with $0.4 \%(\mathrm{w} / \mathrm{v})$ Sulforhodamine B mixed with $1 \%$ acetic acid was performed for $30 \mathrm{~min}$. After five washes of $1 \%$ acetic acid solution, protein-bound dye was extracted with $10 \mathrm{mM}$ tris base solution. Optical density was read at $570 \mathrm{~nm}$ and $\mathrm{IC}_{50}$ (i.e. concentration required to inhibit $50 \%$ of the cells) of each compound was determined. Data was presented as mean $\mathrm{IC}_{50}$ of at least triplicates.

\section{Conclusion}

In this study, new benzoxazole derivatives were designed and synthesized. These benzoxazole derivatives were evaluated for their biological potentials (antimicrobial and anticancer). In vitro antimicrobial results demonstrated that compounds 5, 4, 7 and 16 showed most promising antimicrobial activity against selected microbial species in reference to the standard drugs and in vitro antiproliferative screening results indicated that compounds $\mathbf{4}$ and $\mathbf{1 6}$ showed promising anticancer potential against human colorectal cancer cell line in reference to the standard drugs. These compounds may serve as lead compounds for further development into novel antimicrobial and anticancer agents.

\section{Authors' contributions}

Authors BN, SK and SK have designed, synthesized and carried out the antimicrobial activity and SML, KR, MV and SAAS have carried out the spectral analysis, interpretation and cytotoxicity study of synthesized compounds. All authors read and approved the final manuscript.

\section{Author details \\ ${ }^{1}$ Faculty of Pharmaceutical Sciences, Maharshi Dayanand University, Rohtak 124001, India. ${ }^{2}$ Faculty of Pharmacy, Universiti Teknologi MARA (UiTM), 42300 Bandar Puncak Alam, Selangor Darul Ehsan, Malaysia. ${ }^{3}$ Collaborative Drug Discovery Research (CDDR) Group, Pharmaceutical Life Sciences Com- munity of Research, Universiti Teknologi MARA (UiTM), 40450 Shah Alam, Sel- angor Darul Ehsan, Malaysia. ${ }^{4}$ Department of Pharmacology and Toxicology, College of Pharmacy, Qassim University, Buraidah 51452, Kingdom of Saudi Arabia. ${ }^{5}$ Atta-ur-Rahman Institute for Natural Products Discovery (AuRIns), Universiti Teknologi MARA, 42300 Bandar Puncak Alam, Selangor Darul Ehsan, Malaysia.}

\section{Acknowledgements}

The authors are thankful to Head, Department of Pharmaceutical Sciences, Maharshi Dayanand University, Rohtak, for providing necessary facilities to carry out this research work.

\section{Competing interests}

The authors declare that they have no competing interests.

Ethics approval and consent to participate

Not applicable.

\section{Funding}

Not applicable. 


\section{Publisher's Note}

Springer Nature remains neutral with regard to jurisdictional claims in published maps and institutional affiliations.

Received: 7 June 2018 Accepted: 5 September 2018

Published online: 19 September 2018

\section{References}

1. Parkin DM, Bray F, Ferlay J, P Pisani (2005) Global cancer statistics, 2002. CA Cancer J Clin 55(2):74-108

2. Kamal A, Dastagiri D, Ramaiah MJ, Reddy JS, Bharathi EV, Reddy MK, Sagar MP, Reddy TL, Pushpavalli S, Bhadra MP (2011) Synthesis and apoptosis inducing ability of new anilino substituted pyrimidine sulfonamides as potential anticancer agents. Eur J Med Chem 46(12):5817-5824

3. Stein A, Hiemer S, Schmoll HJ (2011) Adjuvant therapy for early colon cancer current status. Drugs 71(17):2257-2275

4. Yothers G, O'Connell MJ, Lee M, Lopatin M, Clark-Langone KM, Millward C, Paik S, Sharif S, Shak S, Wolmark N (2013) Validation of the 12-gene colon cancer recurrence score in NSABP C-07 as a predictor of recurrence in patients with stage II and III colon cancer treated with fluorouracil and leucovorin (FU/LV) and FU/LV plus oxaliplatin. J Clin Oncol 31(36):4512

5. Ychou M, Hohenberger W, Thezenas S, Navarro M, Maurel J, Bokemeyer C, Shacham-Shmueli E, Rivera F, Kwok-Keung Choi C, Santoro A (2009) A randomized phase III study comparing adjuvant 5-fluorouracil/folinic acid with FOLFIRI in patients following complete resection of liver metastases from colorectal cancer. Ann Oncol 20(12):1964-1970

6. Niu JX, Su ZG, Xiao YY, Huang AW, Li HY, Bao X, Li S, Chen YA, Sun MJ, Ping QN (2012) Octreotide-modified and pH-triggering polymeric micelles loaded with doxorubicin for tumor targeting delivery. Eur J Pharm Sci 45:216-226

7. Yin SP, Li J, Li NN, Wang GJ, Gu XC (2014) Preparation and characterization of long-circulating PELMD/mPEG-PLGA-mixed micelles for 10-hydroxycamptothecin. J Nanopart Res 16:14

8. Chilumula NR, Gudipati R, Ampati S, Manda S, Gadhe D (2010) Synthesis of some novel methyl-2-(2-(arylideneamino)oxazol-4-ylamino)benzoxazole-5-carboxylate derivatives as antimicrobial agents. Int J Chem Res 1(2):1-6

9. Dawood NTA (2011) Synthesis and Antimicrobial Activity of 1-(4-aryl2-thiazolyl)- and 1-(4-aryl-2-oxazolyl)-3,5-diaryl $\Delta^{2}$-pyrazoline derivatives. J Chem Pharm Res 3(4):111-121

10. Ryu CK, Lee RY, Kim NY, Kim YH, Song AL (2009) Synthesis and antifungal activity of benzo[d]oxazole-4,7-diones. Bioorg Med Chem Lett 19(20):5924-5926

11. Moura KCG, Carneiro PF, Carmo MD, Pinto FR, Silva JA, Malta VRS, Simone CA, Dias GG, Jardim GAM, Cantos J, Coelho TS, Silva PEA, Silva EN Jr (2012) 1,3-Azoles fromortho-naphthoquinones: synthesis of aryl substituted imidazoles and oxazoles and their potent activity against Mycobacterium tuberculosis. Bioorg Med Chem Lett 20:6482-6488

12. Eren G, Unlu S, Nunez MT, Labeaga L, Ledo F, Entrena A, Banoglu E, Costantino G, Sahin MF (2010) Synthesis, biological evaluation, and docking studies of novel heterocyclic diaryl compounds as selective COX-2 inhibitors. Bioorg Med Chem Lett 18(17):6367-6376
13. Brandy Y, Ononiwu I, Adedeji D, Williams V, Mouamba C, Kanaan Y, CapelandJr RL, Wright DA, Butcher RJ, Denmeade SR, Bakare O (2012) Synthesis and cytotoxic activities of some 2-arylnaptho[2,3-d]oxazole4,9-dione derivatives on androgen dependent (LNCaP) and androgen independent (PC3) human prostate cancer cell lines. Invest New Drugs 30(4):1709-1714

14. Ashton WT, Sisco RM, Dong H, Kathryn AL, Huaibing H, Doss GA, Leiting B, Patel RA, Wu JK, Marsilio F, Thornberry NA, Weber AE (2005) Dipeptidyl peptidase IV inhibitors derived from $\beta$-aminoacylpiperidines bearing a fused thiazole, oxazole, isoxazole, or pyrazole. Bioorg Med Chem Lett 15(9):2253-2258

15. Zhang W, Liu W, Jiang $X$, Jiang F, Zhuang H, Fu L (2011) Design, synthesis and antimicrobial activity of chiral 2-(substituted-hydroxyl)-3-(benzo[d] oxazol-5-yl) propanoic acid derivatives. Eur J Med Chem 46(9):3639-3650

16. Lin J, Shen W, Xue J, Sun J, Zhang X, Zhang C (2012) Novel oxazolo[4,5-g] quinazolin-2(1H)-ones: dual inhibitors of EGFR and Src protein tyrosine kinases. Eur J Med Chem 55:39-48

17. Padmavathi $V$, Kumara CP, Venkatesh BC, Padmaja A (2011) Synthesis and antimicrobial activity of amido linked pyrrolyl and pyrazolyl-oxazoles, thiazoles and imidazoles. Eur J Med Chem 46(11):5317-5326

18. Hernández D, Altuna M, Cuevas C, Aligué R, Albericio F, Alvarez M (2008) Synthesis and antitumor activity of mechercharmycin a analogues. J Med Chem 51(18):5722-5730

19. Pilch DS, Barbieri CM, Rzuczek SG, LaVoi EJ, Rice JE (2008) Targeting human telomeric G-quadruplex DNA with oxazole-containing macrocyclic compounds. Biochimie 90(8):1233-1249

20. Reddy AB, Hymavathi RV, Swamy GN (2013) A new class of multi-substituted oxazole derivatives: synthesis and antimicrobial activity. J Chem Sci 125(3):495-509

21. Kakkar S, Tahlan S, Lim SM, Ramasamy K, Mani V, Shah SAA, Narasimhan B (2018) Benzoxazole derivatives: design, synthesis and biological evaluation. Chem Cent J 12(92):1-16

22. Kumar S, Lim SM, Ramasamy K, Vasudevan M, Shah SAA, Narasimhan B (2017) Bis-pyrimidine acetamides: design, synthesis and biological evaluation. Chem Cent J 11(80):1-14

23. Kumar S, Lim SM, Ramasamy K, Mani V, Shah SAA, Narasimhan B (2018) Design, synthesis, antimicrobial and cytotoxicity study on human colorectal carcinoma cell line of new 4,4'-(1,4-phenylene)bis(pyrimidin-2amine) derivatives. Chem Cent J 12(73):1-13

24. Cappuccino JC, Sherman N (1999) Microbiology: a laboratory manual. Addison Wesley, California, p 263

25. The Indian Pharmacopoeia Commission (2007) Pharmacopoeia of India vol 1. Controller of publication, Ministry of Health Department, Govt. of India, New Delhi, p 37

26. Skehan P, Storeng R, Scudiero D, Monks A, McMahon J, Vistica D, Warren JT, Bokesch H, Kenney S, Boyd MR (1990) New colorimetric cytotoxicity assay for anticancer-drug screening. J Natl Cancer Inst 82(13):1107-1112

Ready to submit your research? Choose BMC and benefit from

- fast, convenient online submission

- thorough peer review by experienced researchers in your field

- rapid publication on acceptance

- support for research data, including large and complex data types

- gold Open Access which fosters wider collaboration and increased citations

- maximum visibility for your research: over 100M website views per year

At BMC, research is always in progress.

Learn more biomedcentral.com/submissions 